\title{
Composing an Investment Chapter of the Korea-China-Japan FTA: A Quest for Better International Investment Governance?
}

\author{
Won-Mog Choi $^{*}$
}

\begin{abstract}
The Korea-China-Japan Investment Promotion, Facilitation and Protection Agreement is the first treaty in the economic field that binds the three Northeast Asian countries together under a single legal instrument. The existence of effective dispute-settlement procedures under the treaty will contribute to the creation of a favourable investment climate in the host country. Nevertheless, there have been fears about frivolous or vexatious claims that could inhibit legitimate regulatory actions by governments. How to compose an investment chapter of the Korea-China-Japan FTA that is being negotiated is a pressing demand for all in the region. Any pertinent answers to such a quest require a thorough comparison of the benefits and drawbacks of any development of relevant rules and governance. In the end, a quest for better international investment governance in Northeast Asia in the future requires sound evaluation of lessons from the past and present.
\end{abstract}

Key Words: Investment Governance, Investor-State Dispute Settlement, the Korea-ChinaJapan Investment Promotion, Facilitation and Protection Agreement, Korea-China-Japan FTA

JEL Classification: F15, F21, K33

* Law School, EwhaWomans University, Seoul, Korea. Email: wmchoi@ewha.ac.kr. This work is a partially-edited version of a chapter in a book entitled "Regional Cooperation and Free Trade Agreements in Asia" (Brill's Asian Law Series edited by Jiaxiang Hu, Matthias Vanhullebusch, Koninklijke Brill NV, 2014). 


\section{Introduction}

International investment policy-making efforts to attract foreign direct investment (FDI) and benefit from it continue to intensify, and international investment agreements at the bilateral, subregional, regional and interregional levels further proliferate.1) The Northeast Asia is no exception to this prevailing trend.

The Korea-China-Japan Investment Promotion, Facilitation and Protection Agreement ("K-C-J IPPA") 2) was signed on May 13, 2012 after 5 years of negotiation and 10 years of discussions. In the meantime, the bilateral investment treaty (BIT) between Korea and China was amended in 2007 after its entry into force in 1992. Also, there exist the China-Japan BIT (1988) and Korea-Japan BIT (2003). Given this existing system of BITs, the K-C-J IPPA is not an innovative system of investment law in the Northeast Asia. However, it is certainly the first treaty in the economic field that binds the three Northeast Asian countries together under a single legal instrument.

The K-C-J IPPA is appraised to be a lower level of agreement than the Korea-Japan BIT in terms of investment liberalization and protection while being a higher level of agreement than the Korea-China BIT.3) Due to the K-C-J IPPA, the investment system will be put on more stabilized basis in the midst of rapid increase of investment activities among the three countries. The existence of effective dispute-settlement procedures will contribute to the creation of a favourable investment climate in the host country.

Nevertheless, there have been fears about frivolous or vexatious claims that could inhibit legitimate regulatory actions by governments, as well as concerns with regard to balancing national and international methods of dispute settlement. In addition, the rather vague language of some treaty provisions and the increasing complexity of investment treaty provisions can make the outcome of arbitration less predictable. ${ }^{4)}$ How to harmonize with domestic judicial systems is also an issue of debate. These fears, concerns and debate have already been raised globally and in Northeast Asia particularly during the process of negotiation and ratification of the Korea-US FTA and K-C-J IPPA.5)

In this regard, main substantive and procedural provisions of the K-C-J IPPA need

1) $\operatorname{UNCTAD}(2005)$, p. 3.

2) Agreement Among the Government of Japan, the Government of the Republic of Korea and the Government of the People's Republic of China for the Promotion, Facilitation and Protection of Investment.

3) According to the K-C-J IPPA, an investor may selectively rely on a more favourable agreement among bilateral and trilateral agreements that are available. Article 25 of K-C-J IPPA.

4) Supra note 1.

5) Free Trade Agreement between the Republic of Korea and the United States of America, signed on 30 June 2007, entered into force on 15 March 2012. 
thorough evaluation in comparison with the Korea-US FTA. The question whether the ISDS paradigm in the K-C-J IPPA will function as a model for the Asian integration depends on how to identify the drawbacks through this evaluation. The allowance of direct claims by investors in the three Northeast Asian countries pursuant to the common rules of game will help to engender a community spirit in the region. This basis will function as a stepping stone toward a system of Korea-China-Japan economic integration.

In this light, how to compose an investment chapter of the Korea-China-Japan FTA ("K-C-J FTA") that is being negotiated is a pressing demand for all in the region. Any pertinent answers to such a quest require a thorough comparison of the benefits and drawbacks of any development of the governance. In this light, Chapters II and III will review substantive provisions and dispute settlement provisions of K-C-J IPPA to examine how to improve those rules in the K-C-J FTA. In the end, a quest for better international investment governance in Northeast Asia in the future requires sound evaluation of lessons from the past and present.

\section{Composing Substantive Provisions of Investment Chapter of K-C-J FTA}

\subsection{Definition of Investment and Scope of Protection}

The K-C-J IPPA sets forth a broad definition of investment and thus, a comprehensive scope of protection for investors. As necessary characteristics of an "investment", the agreement indicates "commitment of capital or other resources, the expectation of gain or profit, or the assumption of risk,"6) and includes into the scope of investment such forms as "an enterprise; equity participation; debt; rights under contracts; claims to money; intellectual property rights; rights conferred pursuant to laws and regulations or contracts such as concessions, licenses, authorizations and permits; and any other tangible and intangible, movable and immovable property, and any related property rights."7)

This definition is based on the definition of investment under the model BIT of the United States 8 ) and is largely adopted by high-level BITs and FTAs. The three characteristics, such as (i) commitment of capital or other resources, (ii) the expectation of gain or profit, or (iii) the assumption of risk, are widely indicated as the features of investment in many BITs and FTAs. Moreover, in such an investment case as Salini v.

\footnotetext{
6) Article 1 (1), K-C-J IPPA.

7) Ibid.

8) 2004 Model BIT, Department of States, the United States Government.
} 
Morocco9), the arbitral tribunal identified the following four elements as indicative of an investment for purposes of the ICSID Convention: (i) a contribution, (ii) a certain duration over which the project is implemented, (iii) a sharing of operational risks, and (iv) a contribution to the host state's development. ${ }^{10)}$

Note should be taken of the fact that an important difference exists. In the Salini test, the four elements were understood to be closely interrelated and thus, they need to be examined in their totality. ${ }^{11)}$ By contrast, in the K-C-J IPPA and the model BIT, the three elements are linked by the word "or" (not "and")12). This means that one can even argue that those elements are respectively stated as independent and sufficient ones: if only any one of those three elements is met, there exists an investment. This also means that the scope of investment may reach too far, thereby subjecting overly broad area into the coverage of treaty protection.

Concerning the form of "rights under contracts", it is debatable whether any contractual right is eligible to be an investment. ${ }^{13)}$ Indeed, if a legal system adopts the strong principle of freedom of contract, there can arise various rights from contracts. Infringement of any of such rights by a host government can easily subject it to an investor-state dispute claim by the right holder under such a comprehensive definition of investment.

Whether a particular type of "concessions, licenses, authorizations, and permits" has the characteristics of an investment must depend on such factors as the nature and extent of the rights that the holder has "pursuant to laws and regulations". In other words, among concessions, licenses, authorizations or permits that do not have the characteristics of an investment are those that do not create any rights protected under domestic law.

With respect to the category of "any other tangible and intangible, movable and immovable property, and any related property rights", it needs to be noted that such benefits as market share, market access, expected gains, and opportunities for profit-making should

9) Saline CostruttoriSpA v. Morocco (ICSID Case No. ARB/00/4, 2001, 42 ILM, 2003).

10) Ibid., para 130. This is the so-called "Salini test".

11) Ibid. See also L.E.S.I. v. Algeria, Award of 27 December 2004, para. 13(iv); available at http://www.worldbank.org/icsid/cases/lesi-sentence-fr.pdf [JTB 24]. .

12) "The term 'investments' means every kind of asset that an investor owns or controls, directly or indirectly, which has the characteristics of an investment, such as the commitment of capital or other resources, the expectation of gain or profit, or the assumption of risk." Article 1 (1) of K-C-J IPPA (emphasis added).

13) In Siemens v. Argentina, a suspension of contract (a contract to establish a system of migration control and personal identification) by the new government of Argentina was challenged by Siemens. What was ruled as investment by the tribunal is not any contractual right, but "claims to money that has been used to create economic value or claims to any performance under a contract having an economic value". See para 150 of Decision on Jurisdiction, Siemens A.G. v. the Argentine Republic (ICSID Case No. $\mathrm{ARB} / 02 / 8)$. 
not be, by themselves, investments.

All of these points can be reflected into a definition clause of investment in the K-C-J FTA, according to which the three characteristics -- (i) commitment of capital or other resources, (ii) the expectation of gain or profit, and (iii) the assumption of risk-are required to be considered in a cumulative manner for the purpose of determining any existence of investment. This will also make the definition of investment fully consistent with the Salinitest.

Based on the broad notion of investment, the K-C-J IPPA stipulates such comprehensive obligations as the promotion and protection of investment, general treatment of investment, most-favoured-nation(MFN) treatment, transparency, expropriation and compensation, compensation for losses or damages, and freedom of transfers. On the other hand, the agreement does not protect the pre-investment stage by stating that the term "investment activities" means "management, conduct, operation, maintenance, use, enjoyment and sale of other disposition of investments". 14) This approach seems to find a balance between efforts to build a high-level system of investment protection and to setout a cautious scope of protected stages of investment transaction.

\subsection{Non-discrimination Principle and General Treatment of Investment}

This balanced approach is also reflected to the national treatment clause. In the K-C-J IPPA, the golden rule of national treatment does not apply to "non-conforming measures, if any, existing at the date of entry into force of this Agreement". ${ }^{15}$ ) This blanket exemption of any existing non-conforming measures from the application of the golden rule helps signatory parties to preserve existing policy discretion.

On the other hand, the exemption is conditioned upon the so-called "ratchet" and "no less favourable than before" clause. That is, in order to claim this exemption, the amendment or modification of existing non-conforming measures must "not decrease the conformity of the measures as it existed immediately before the amendment or modification" and the treatment granted to an investment once admitted shall "in no case be less favourable than that granted at the time when the original investment was made."16) These conditions are setting limitation of the policy discretion.

The investment chapter of the K-C-J FTA needs to adopt this negative listing approach combined by non-conforming measures in that it can achieve high-level protection of

\footnotetext{
14) Article 1 (5), K-C-J IPPA.

15) Article 3 (2), K-C-J IPPA.

16) Ibid.
} 
investment while preserving necessary regulatory discretion for the signatory parties.

Application of the MFN principle in the K-C-J IPPA is subject to significant exceptions: the principle does not apply to any preferential treatment resulting from regional trade agreements, any international arrangement for facilitating small scale trade in border areas, or aviation, fishery and maritime agreements. ${ }^{17)}$ Also, the MFN principle does not apply in regard to provisions concerning the settlement of investment disputes, ${ }^{18)}$ and matters related to the acquisition of land property. ${ }^{19)}$

An MFN clause needs to be included in the investment chapter of K-C-J FTA. The MFN guarantee exchanged among the three host states in Northeast Asia will facilitate the internal investment flow in the region. With respect to the scope of exception, excepting"any preferential treatment resulting from regional trade agreements" from the MFN principle needs to be avoided in the K-C-J FTA. In this era of proliferating FTAs, where most of investment preferences are accorded through FTAs, the MFN principle may become meaningless if such preferences through FTAs are not subject to the principle. Having said this, one legislative option would be to provide that only excepted from the MFN principle are any preferences resulting from regional trade agreements entered into force prior to the effectuation of the K-C-J FTA. In other words, should Korea, China, and Japan accord preferential treatments to the investment or investor of any non-parties in the future, such treatments are obliged to be accorded to investments or investors of the three countries. This type of "future MFN clause" in the K-C-J FTA will make its MFN guarantee substantially meaningful.

Access to the courts of justice clause in the K-C-J IPPA requires each contracting party to accord the MFN and national treatment to the investors of another party with respect to access to the courts. ${ }^{20)}$ It does not require treatments pursuant to a minimum standard in customary international law differently from the case of many BITs and FTAs. This means that each party may operate the justice system in accordance with its own standard in so far as it is non-discriminatory.

This contrasts with the general treatment of investments clause in the K-C-J IPPAthat adopts a "reasonable and appropriate standard of treatment accorded in accordance with generally accepted rules of international law".21)

Given the differences in the system of access to the courts of justice between Korea and Japan on one hand, and China on the other, it will be difficult for the K-C-J FTA to

\footnotetext{
17) Article 4(2), K-C-J IPPA.

18) Ibid., Article 4(3).

19) Para 1 of the Protocol of K-C-J IPPA.

20) Article 6, K-C-J IPPA.

21) Article 5(1), K-C-J IPPA.
} 
require any minimum standard of treatment in terms of the access to the courts. Therefore, the non-discriminatory treatment obligations can form the basis of the access to the courts of justice clause in the K-C-J FTA. Other aspects of the general treatment of investment may be dealt with by generally accepted standards of international law.

\subsection{Prohibition of Performance Requirements, Entry of Personnel, and Intellectual Property Rights}

The K-C-J IPPA delimits the prohibition rule of performance requirements within the level of WTO TRIMS (Agreement on Trade-Related Investment Measures), and performance requirements on export or transfer of technology are prohibited only if they are unreasonable or discriminatory.22) In other words, any performance requirements on export or transfer requirements of technology are permitted as long as they are reasonable and non-discriminatory.

In negotiating the K-C-J FTA, parties need to endeavor to adopt a full-fledged provision on performance requirements that prohibits any requirements:

(a) To export a given level or percentage of goods or services;

(b) To achieve a given level or percentage of domestic content;

(c) To purchase, use, or accord a preference to goods produced in its territory, or to purchase goods from persons in its territory;

(d) To relate in any way the volume or value of imports to the volume or value of exports or to the amount of foreign exchange inflows associated with such investment;

(e) To restrict sales of goods or services in its territory that such investment produces or supplies by relating such sales in any way to the volume or value of its exports or foreign exchange earnings;

(f) To transfer a particular technology, a production process, or other proprietary knowledge to a person in its territory; or

(g) To supply exclusively from the territory of the Party the goods that such investment produces or the services that it supplies to a specific regional market or to the world market. 
Moreover, any measure that conditions the receipt of an advantage on compliance with some of the above requirements can also be prohibited.

With these strong provisions addressing performance requirements, parties may still agree on certain exceptions and the scope of non-conforming measures.

According to the K-C-J IPPA, each party must endeavor, "to the extent possible, in accordance with its applicable laws and regulations," to facilitate the procedures for the entry, sojourn and residence of investors of another party. ${ }^{23)}$ This means that entry of personnel is not absolutely guaranteed as a matter of right of investors. In negotiating the K-C-J FTA, parties can make efforts to create certain treaty rights of temporary entry for at least certain groups of professionals including corporate or independent investors. In doing so, sensitive regulations may be prescribed as non-conforming measures.

Interestingly, the K-C-J IPPA has the provision for IPR protection that "Each Contracting Party shall, in accordance with its laws and regulations, protect intellectual property rights." This obligation "shall not be construed so as to derogate from the rights and obligations under international agreements" in respect of protection of IPRs to which two or more contracting parties are parties, and the MFN principle does not apply in regard to this IPR protection rule.24)

Given that the definition of investment in the K-C-J IPPA includes IPRs, these provisions play a role to allow parties to accord investment protection to IPRs in accordance with their own domestic standards, not with treaty standards. It would be better if the three countries could agree to accord treatments under the K-C-J FTA to IPRs as a matter of principle: any sensitive issues can be covered by adding non-conforming measures.

\subsection{Expropriation and Compensation}

With respect to the obligation of expropriation and compensation, the K-C-J IPPA obliges parties to compensate indirect expropriation as well as direct expropriation. Indirect expropriation is defined as "an action or a series of actions by a contracting party" that has an "effect equivalent to direct expropriation" and whether or not such effect has occurred requires a case-by-case, fact-based inquiry that considers economic impact on the investment, interference with distinct and reasonable expectations arising out of investment, and the character and objectives of such an action. ${ }^{25)}$ Except in rare circumstances,

\footnotetext{
23) Article 8, K-C-J IPPA.

24) Article 9, K-C-J IPPA.

25) Para. 2, Protocol of K-C-J IPPA.
} 
non-discriminatory regulatory actions adopted by a party for the purpose of legitimate public welfare do not constitute indirect expropriation. 26$)$

These provisions of indirect expropriation are an exact copy of the 2004 model BIT text of the United States. The similar rules of indirect expropriation have been spread worldwide through BITs and FTAs by the U.S. initiative. It can be argued that the term "an action or a series of action" is not clear and too much inclusive and it might apply in an arbitrary manner to restrict many legitimate governmental regulations. Originally, the term "an action or a series of actions" was drafted to catch a situation of the so-called "creeping expropriation", where the host country government imposes the continual restriction of investment property rights gradually over time through various legislation and regulations in order to infringe upon investor's activities. This original intention notwithstanding, the current text is interpreted to catch as indirect expropriation any "action or a series of action" that is even not directed toward the investment, as long as such an action causes an "effect equivalent to direct expropriation". It is because there are stated only two elements to constitute indirect expropriation, i.e. action and effect.

Taking an example that shows a seriousness of this problem, the Ministry of Education (MOE) of the Korean Government recently considered developing an English testing service for the people who want to prove their English language proficiency. In the Korea-US FTA, Korea agreed to liberalize the sector of foreign language testing service. As the FTA has a similar definition clause of indirect expropriation to that of the K-C-J IPPA, the ETS (a U.S.-based company who has made a substantial investment to Korea) might bring a complaint that this MOE project constitutes an indirect expropriation as an action that will cause a damaging effect on its existing English proficiency test service, i.e. TOEFL.

This kind of scenario is always possible given the loose definition of indirect expropriation, no matter how legitimate purpose the regulating government has. The same problem may occur in the K-C-J IPPA which copies the definition under the U.S. model BIT.

In order to solve this problem, the K-C-J FTA could use the term "a measure or a series of measures directed toward a covered investment" instead of "an action or a series of actions" as the definition of indirect expropriation. Otherwise, a possibility is always latent that an incidental action that is not intended to restrict investments might be caught as an indirect expropriation by the only reason that a damaging effect has occurred to the investment. 


\subsection{Exceptions}

As in most BITs and FTAs, the K-C-J IPPA announces the principle of non-application to taxation measures. Nonetheless, expropriation and compensation provisions are an exception to this non-application. According to the trilateral agreement, the agreement does not generally apply to taxation measures and in the event of any inconsistency between the K-C-J IPPA and any tax convention, the latter will prevail.27) The caveat is that the expropriation and compensation provision in the K-C-J IPPA applies to taxation measures and that any disputes concerning this matter are resolved by the investor-state dispute settlement (ISDS).

Therefore, it becomes a critical question whether a tax measure is an expropriation or not. According to the K-C-J IPPA, this question is not answered by objective criteria spelled out in the agreement. Instead, the determination is made by a joint decision-making process of tax authorities of the both contracting parties involved. That is to say, the disputing investor must refer the issue, at the time of the submission of a written request for consultation, to the competent authorities of the both countries to determine whether such measure is not an expropriation. If the competent authorities do not consider the issue or, having considered it, fail to determine that the measure is not an expropriation within six months, the investor may submit its claim to the ISDS arbitration.28)

This joint decision process seems to reinforce the sovereign authority over taxation matters: unless competent authorities of both countries involved recognize the existence of expropriation regarding a tax measure, there is no way for the investor to move on to the ISDS arbitration. Indeed, a tax authority of the host country will seldom acknowledge any existence of expropriation created by its own tax measure.

It is true that the imposition of taxes does not generally constitute an expropriation. However, tax measures if taken in overly excessive and arbitrary manner may have an equivalent effect to the expropriation. In this light, the K-C-J FTA should not adopt the joint decision process to exclude virtually all tax measures from the scope of expropriation. Instead, the FTA could prescribe the following criteria:

(a) The imposition of taxes does not generally constitute an expropriation. The mere introduction of a new taxation measure or the imposition of a taxation measure in more than one jurisdiction in respect of an investment generally does not in and of itself constitute an expropriation;

27) Article 21, K-C-J IPPA.

28) Ibid. 
(b) A taxation measure that is consistent with internationally recognized tax policies, principles, and practices should not constitute an expropriation. In particular, a taxation measure aimed at preventing the avoidance or evasion of taxation measures generally does not constitute an expropriation;

(c) A taxation measure that is applied on a non-discriminatory basis, as opposed to a taxation measure that is targeted at investors of a particular nationality or at specific taxpayers, is less likely to constitute an expropriation; and

(d) A taxation measure generally does not constitute an expropriation if it was already in force when the investment was made and information about the measure was publicly available. ${ }^{29)}$

The second exception where the K-C-J IPPA does not apply is "the measures relating to financial services for prudential reasons, including measures for the protection of investors, depositors, policy holders or persons to whom a fiduciary duty is owed by an enterprise supplying financial services, or to ensure the integrity and stability of the financial system". ${ }^{30)}$ Such a prudential measure exception in the K-C-J IPPA shows that the maintenance of stable financial system is the common goal in priority in the Northeast Asia. Note needs to be taken that such an exception should not be used as a means of avoiding the contracting party's obligations under the agreement. ${ }^{31)}$ This prudential measure exception needs to be copied in the K-C-J FTA.

Other exceptions are security exceptions and temporary safeguard measures. ${ }^{32)}$ The security exception provision must not be used as a means of avoiding the contracting party's obligations. ${ }^{33)}$

The problem is that there is no general exception clause in the K-C-J IPPA. According to Article XIV of GATS, several measures are generally excepted from the obligations under the agreement, which include (i) measures necessary to protect public morals or to maintain public order; (ii) measures necessary to protect human, animal or plant life or health; and (iii) measures necessary to secure compliance with laws or regulations relating to the prevention of deceptive and fraudulent practices, the protection of the privacy of individuals, and safety. ${ }^{34)}$

\footnotetext{
29) See Annex 11-F (Taxation and Expropriation), Korea-US FTA.

30) Article 20(1), K-C-J IPPA.

31) Article 20(2), K-C-J IPPA.

32) Articles 18, 19, K-C-J IPPA.

33) Article 18(2), K-C-J IPPA.

34) Article XIV, GATS.
} 
It can be reminded that the third mode of service supply under the GATS (the so-called "commercial presence" mode) is related to the investment. This means that general exceptions equivalent to GATS Article XIV deserve to apply to any investment activities. Considering that many BITs and FTAs include a general exception clause in light of this spirit,35) the investment chapter of the K-C-J FTA needs to incorporate such exceptions.

\section{Composing Dispute Settlement Procedure Provisions of Investment Chapter of K-C-J FTA}

In order to secure compliance with substantive rules, the K-C-J IPPA establishes the procedure of investor-state dispute settlement system(ISDS).

\subsection{Who May Raise ISDS Claim?}

The person who can bring an ISDS complaint is called a "disputing investor" and the disputing investor means "a natural person or an enterprise of a Contracting Party that makes investments in the territory of another Contracting Party." person of a Contracting Party" means "a natural person that has the nationality of that Contracting Party in accordance with its applicable laws and regulations"37), and the term "enterprise of a Contracting Party" means "any legal person or any other entity constituted or organized under the applicable laws and regulations of that Contracting Party, whether or not for profit, and whether private or government-owned or controlled, and includes a company, corporation, trust, partnership, sole proprietorship, joint venture, association or organization." "A branch of an enterprise" is not deemed to be an enterprise. 38 )

This means that nationality of investors is a deciding factor to determine eligibility to bring an ISDS claim. What if a real investor is a non-national of contracting parties while an enterprise is established under the name of a national of a contracting party to use the channel of ISDS? In order to deny any benefit of ISDS to such a case, the K-C-J IPPA has a

35) Korea-Singapore FTA Article 21.2; Korea-India CEPA Article 10.16 (health, safety and Environmental measures), Article 10.18 (exceptions); Korea-EU FTA Article 7.50 (Exceptions); Investment Agreement of the Korea-EFTA FTA Article20 (Exceptions); Korea-Peru FTA Article 9.9 (health, safety and environmental measures), Article 24.1 (general exceptions). See also many BITs including Article 16 of the Korea-Japan BIT.

36) Article 1 (2), K-C-J IPPA.

37) Article 1 (3), K-C-J IPPA.

38) Article 1 (4), K-C-J IPPA. 
denial of benefits clause, according to which the following investors and investments are denied of their benefits to use the agreement:

(i) an investor of another Contracting Party and its investment if the enterprise is owned or controlled by an investor of a non-Contracting Party and the denying Contracting Party does not maintain normal economic relations with the non-Contracting Party;

(ii) an investor of another Contracting Party and its investment if the enterprise is owned or controlled by an investor of a non-Contracting Party and the denying Contracting Party adopts or maintains measures with respect to the non-Contracting Party that prohibit transactions with the enterprise or that would be violated or circumvented if the benefits of this Agreement were accorded to the enterprise or to its investments; ${ }^{39}$ )or

(iii) an investor of another Contracting Party and its investments if the enterprise is owned or controlled by an investor of a non-Contracting Party or of the denying Contracting Party, and the enterprise has no substantial business activities in the territory of the latter Contracting Party. 40 )

For this purpose, the term "non-Contracting Parties" does not include any separate customs territory within the meaning of WTO Agreement. ${ }^{41)}$ This means that Chinese enterprises owned or controlled by investors of Hong Kong or Macau are not denied of their benefits to bring ISDS claims against Korea or Japan.

This type of denial of benefits clause is largely equivalent to that of Korea-US FTA, which is a typical FTA equipped with a very strong denial of benefits provision. This needs to be adopted by the K-C-J FTA. Such provisions will inhibit the possibility that an enterprise of a country in abnormal economic relations or with prohibited transactions may request protections under the FTA. Furthermore, it will prohibit an investment established in the territory of a contracting party by an enterprise of a country in normal relations from using the agreement if substantial business activities are not conducted in such a territory itself.

Albeit their effectiveness, how to interpret such words as "normal economic relations" and "prohibition of transactions" is debatable. Is North Korea in normal economic relations with South Korea and Japan? Given that the Inter-Korean Basic Agreement was signed in

\footnotetext{
39) Article 22 (1), K-C-J IPPA

40) Article 22 (2), K-C-J IPPA.

41) Ibid.
} 
1991 and selective level of inter-Korean trade was legitimized, it could be argued that North Korea is no longer in abnormal economic relations with South Korea. Nonetheless, if the South Korean government prohibits trade with the North such as the case that happened in the aftermath of the Yeonpyeong bombardment incident, ${ }^{42)}$ Korea may deny the benefits of the K-C-J IPPA to Chinese enterprises owned or controlled by a North Korean person.

Note needs to be taken of the fact that according to the denial of benefits clause of K-C-J IPPA, a contracting party may not deny the benefits of an enterprise owned or controlled by its own national if the enterprise is conducting substantial business activities in another contracting party. For example, one of Korean large corporations may use its subsidiary in China or Japan to challenge a regulatory policy of the Korean government through ISDS mechanism in the K-C-J IPPA. In this case, Korea cannot invoke the denial of benefits clause, as long as the subsidiary is doing substantial business activities in China or Japan. Given the anti-Jaebol (large corporations) sentiment among the Korean public, this kind of roundabout challenge against regulatory policies of its own government, if it happens, will open a great social debate in Korea.It seems that the Korean government needs to pay consideration of how to compose the denial of benefits clause of the K-C-J FTA in order to prevent this from happening.

\subsection{Causes of the Claim}

A typical cause of the ISDS claim is the breach of obligations under an investment agreement. In this regard, the K-C-J IPPA confirms this cause of claim by indicating "a dispute between a Contracting Party and an investor of another Contracting Party that has incurred loss or damage by reason of, or arising out of, an alleged breach of any obligation of the former Contracting Party under this Agreement". ${ }^{43)}$

On the other hand, BITs and FTAs initiated by the United States tend to add other causes of claim. For example, the Korea-US FTA adds breaches of "an investment authorization" or "an investment agreement" on top of the breaches of treaty obligations. ${ }^{44)}$ In other words, this provision recognizing these additional causes of claim (called "Umbrella Clause") play a role of elevating otherwise contractual claims to treaty claims subject to the ISDS.

Attention needs to be paid to that the words "any obligation" in the phrase of "a breach

\footnotetext{
42) North Korea shot bombs onto Yeonpyeong Island in Yellow Sea in November 2010, which resulted civilian casualties. In return, South Korea took a comprehensive economic countermeasure including the trade ban with the North.

43) Article 15 (1), K-C-J IPPA.

44) Article 11.16.1(a), Korea-US FTA.
} 
of any obligation under this Agreement" in the K-C-J IPPA includesthe obligation arising from Article 5.2 of the agreement. According to Article 5.2, each contracting party "shall observe any written commitments in the form of an agreement or contract it may have entered into with regard to investments of investors of another Contracting Party." In this regard, "any written commitments" may well include, among others, commitments arising from any investment authorization or investment agreement. Given the above, it can be said that the K-C-J IPPA allows comprehensive causes of claim, even more comprehensive than the causes of claim under the Korea-US FTA.

Different from the cases of a breach of treaty obligations, any legal disputes concerning the breach of investment authorization or investment agreement are basically a matter subject to the domestic law. In other words, there is no sound rationale for the Umbrella Clause that elevates inherently domestic law claims to international claims. This possible criticism about the Umbrella Clause makes it necessary to reconsider the presence of such a clause in the K-C-J FTA.

It should be noted that the K-C-J IPPA sets out several of treaty obligations outside the subject matter of ISDS claims. Such obligations include the obligation to maintain transparent IPR regime, obligation to promote cooperation and communications in the IPR field, and the prudential measures provision. Against any breach of such obligations, investors may have recourse only to domestic court proceedings. ${ }^{45)}$

\subsection{Arbitral Procedures}

Any investment dispute must, as far as possible, be settled amicably through consultation between the disputing investor and the contracting party in dispute. According to the K-C-J IPPA, a written request for consultation must be submitted to the contracting party by the disputing investor, which specifies "the name and address of the disputing investor, the obligations alleged to have been breached, a brief summary of the facts of the investment dispute, and the relief sought and the approximate amount of damages."46)

Such detailed information about the dispute is not required to be submittedupon requesting consultations in most of other BITs and FTAs. For example, in the Korea-US FTA, there is no particular requirement for the request of consultation and if the consultation fails, at least 90 days before submitting any claim to arbitration, a claimant must deliver to the respondent a written notice of its intention to submit the claim to arbitration, in which the name and address of the claimant, the obligations alleged to have

\footnotetext{
45) Article 15 (12), K-C-J IPPA.

46) Article 15 (2), K-C-J IPPA.
} 
been breached, the legal and factual basis for each claim, and the relief sought and the approximate amount of damages claimed need to be specified. ${ }^{47)}$

This means that the K-C-J IPPA requires a notification of information at the early stage of consultation that is otherwise notified by the notice of intention to submit the claim to arbitration. This early provision of information will facilitate the consultation procedure by supplying a sufficient amount of information to reach mutual understandings of facts and damages. It will also contribute to amicable settlements of the disputes before the legal battle: a reflection of Asian culture of avoiding judicial proceedings.

When the disputing investor submits a written request for consultation, the disputing contracting party may require, without delay, the investor to go through the domestic administrative review procedure specified by the laws and regulations of that contracting party before the submission to the arbitration. The domestic administrative review procedure must not exceed four months from the date on which an application for the review is filed. If the procedure is not completed by the end of the four months, the disputing investor may submit the dispute to the arbitration. ${ }^{48)}$ It is understood that any decision made under the domestic administrative review procedure must not prevent the investor from submitting the dispute to the arbitration. ${ }^{49)}$ If the domestic review procedure is not requested, the consultation must last for four months at minimum.50)

In FTAs to which Korea is party, the disputing investor may request arbitration without undergoing the domestic review procedure. On the other hand, China tends to require a prior domestic review in its FTAs. ${ }^{51)}$ It seems that this Chinese position was adopted during the negotiation of the K-C-J IPPA to give birth to the current requirement of domestic administrative review procedure.

During the negotiation and ratification of the Korea-US FTA, criticisms were raised inside Korean legal communities against the ISDS mechanism that enables the disputing investor to proceed to arbitration by bypassing any domestic review procedures. Given these criticisms, the requirement of domestic administrative review prior to the arbitration in the K-C-J IPPA deserves credit. Moreover, a possible problem of time delay arising from the requirement of domestic procedure is effectively solved by the imposition of time limit of four months for the procedure. Mandatory period of consultation is set at "four months

47) Article 11.16.2, Korea-US FTA.

48) Article 15.7, K-C-J IPPA.

49) Ibid., note.

50) Article 15.3, K-C-J IPPA.

51) For example, Article 153.2 of China-New Zealand FTA ("Upon the receipt of a notice referred to in paragraph 1, the state party may require the investor concerned to go through any applicable domestic administrative review procedures specified by the laws and regulations of the state party, which may not exceed 3 months, before the submission of the claim to arbitration under paragraph 1(a) or 1(b)"). 
from the date of the submission of the written request." This is a relatively shorter period compared to "six months after the request of consultation" in the Korea-ASEAN FTA and "six months since the events giving rise to the claim" in the Korea-US FTA. 52)

Given these merits, such domestic administrative review requirement for a relatively short period of time needs to be adopted by the K-C-J FTA. As alternative, it could be designed that only claims subject to the prior domestic review procedures are such disputes concerning the breach of investment authorization or investment agreement. It is because given the nature of these disputes as a domestic legal claim, an adjudicatory body of domestic law needs to have a chance to handle the case.

In general, domestic procedures and international arbitration may overlap to render mutually inconsistent decisions if the disputing investor chooses to use both tracks. In order to avoid this situation, two approaches have been taken in BITs and FTAs. The folk-in-the-road approach requires a disputing investor to select one of the two procedures and if chosen, the other procedure becomes no more available. The Korea-ASEAN FTA is an example of the folk-in-the-road approach.

On the other hand, the Korea-US FTA adopts the waiver approach. According to this approach, once the investor initiates a domestic remedy procedure, he or she may have recourse to the arbitration procedure if a written waiver of abandoning domestic procedures has been submitted. ${ }^{53)}$

Between these two approaches, the K-C-J IPPA adopts the folk-in-the-road approach. Once the disputing investor has submitted an investment dispute to the competent court of the disputing contracting party or to one of the arbitrations, the choice of the disputing investor is final and the investor may not submit thereafter the same dispute to the other arbitrations. ${ }^{54)}$ This approach can be copied by the K-C-J FTA because it can effectively prevent any forum shopping behaviors from happening and induce a genuine and sincere choice of forum by the claimant.

In the Korea-US FTA, unless the disputing parties otherwise agree, the tribunal must comprise three arbitrators: one arbitrator appointed by each of the disputing parties and the third, who will be presiding arbitrator, appointed by agreement of the disputing parties. ${ }^{55)}$ If a tribunal has not been constituted within 75 days of the date a claim is submitted to arbitration, the Secretary-General of ICSID, on the request of a disputing party, must appoint, in his or her discretion, the arbitrator or arbitrators not yet appointed among non-nationals of either party. ${ }^{56)}$

\footnotetext{
52) Article 11.16.3, Korea-US FTA.

53) Article 11.18.2, Korea-US FTA.

54) Article 15 (5), K-C-J IPPA.

55) Article 11.19.1, Korea-US FTA.
} 
This kind of special provision of appointing arbitrators is not included in the K-C-J IPPA. During the Korea-US FTA negotiation and ratification process, critics raised their concerns about the possibility that this special provision might increase likelihood of pro-American arbitrators being appointed as arbitrators in an ISDS dispute between Korea and the United States because the Secretary-General of ICSID, who is under the influence of the World Bank President, plays a key role in the appointing process.

As a consequence of having no special provision, if ICSID rules are adopted in an ISDS case under the K-C-J IPPA, the arbitrator selection provisions under the ICSID Convention will apply without any modification. According to the Arbitration Rules of ICSID Convention, 57) if the tribunal is not constituted within 90 days, the Chairman of the Administrative Council is supposed to appoint arbitrators after consultation with both parties. ${ }^{58)}$ As the Chairman is seconded ex officio by the President of the World Bank, 59) it is ironic to say that the very person whom the Korean public had concerns with will play a key role in appointing arbitrators in ISDS disputes under the K-C-J IPPA.

In ISDS claims among Korea, China, and Japan, it is unlikely to cause an unfairness problem if Secretary-General of ICSID or President of the World Bank appoints the chairperson. Therefore, the K-C-J FTA can use either person as the appointing authority of the presiding arbitrator.

ISDS claims are subject to a time limit. No claim may be submitted to the arbitration under the K-C-J IPPA, if more than three years have elapsed from the date on which the disputing investor first acquired, or should have first acquired, whichever is the earlier, the knowledge that the disputing investor had incurred the loss or damage.60) This three year time limit is universally adopted by most investment treaties. There seems to be no reason that the K-C-J FTA should digress from the standard term.

\subsection{Arbitral Awards and Implementation}

As in the most BITs and FTAs, the K-C-J IPPA declares that the arbitral award which is rendered by the tribunal is final and binding upon both parties to the investment disput e.61) Remedies are awarded in terms of monetary damages. That is, although a restitution of property is awarded, the disputing contracting party may pay monetary damages in lieu of

\footnotetext{
56) Article 11.19.3, Korea-US FTA.

57) Rules of Procedure for Arbitration Proceedings.

58) Ibid., Rule 4,

59) Article 5, ICSID Convention.

60) Article 15.11, K-C-J IPPA.

61) Article 15.10, K-C-J IPPA.
} 
restitution. 62$)$

Because an ISDS has a nature of commercial arbitration at least in part, the principle of monetary damages needs to be respected, differently from any diplomatic protection procedures where the remedy rule of restitution prevails. The ISDS in the K-C-J FTA can follow this tradition.

On the other hand, how to prevent frivolous claims by investors is becoming an important issue in the ISDS mechanism. In particular, if a treaty is equipped with a broad range of causes of claim through an umbrella clause, the possibility of frivolous claims tends to increase. One possible solution could be to introduce the loser-pay rule in the K-C-J FTA where the entire costs of ISDS proceedings are imposed upon the losing party. As alternative, arbitral tribunals could be required to apply the loser-pay rule if they have found frivolous claims.

\section{Conclusion}

It is uncertain whether the K-C-J IPPA model can play a pioneering role in the ongoing process of convergence of investment jurisprudence in Asia. Nonetheless, the implications of the investment treaty system and ISDS procedures are gaining more attention as foreign investors are increasingly making investment into Northeast Asia.

The allowance of direct claims by investors in the three Northeast Asian countries pursuant to the common rules of game will help to engender a community spirit in the region. This basis will function as a stepping stone toward a system of Korea-China-Japan economic integration. Furthermore, it may eventually have a significant political importance and spillover effect to other fields by building a leverage to resolve territorial disputes, to ease antagonistic national sentiments, and to prevent threats to national security in the region.

Any pertinent answers to such a quest for the better international investment governance in the region require a thorough comparison of the benefits and drawbacks of any development of the governance. In the end, a successful governance needs a continuous process of revision and balancing. Lessons from the experiences under the K-C-J IPPA system and its modification efforts in composing an investment chapter in the K-C-J FTA should be fully taken into account so that the newly emerging investment governance system will not lead to tension between nations in an area where precedent is scant, but the need is great.

62) Article 15.9, K-C-J IPPA. 


\section{References}

Maclachlan, C. et al. (2007),International Investment Arbitration, USA: Oxford University Press.

Bishop, D., et al. (2005) Foreign Investment Disputes- Cases, Materials and Commentary, The Hague: Kluwer Law International.

Choi, Won-Mog (2007) "The Present and Future of the Investor-State Dispute Settlement Paradigm,"Journal of International Economic Law. 1-23.

Rudolf, D. and Schreuer, C. (2008) Principles of International Investment Law, USA: Oxford University Press.

Julian, L. et al. (2003) Comparative International Commercial Arbitration, The Hague: Kluwer Law International.

Merrills, J. (2005) International Dispute Settlement, Cambridge: Cambridge University Press.

OECD (2006) Improving the System of Investor-State Dispute Settlement: An Overview, Paris: OECD Publishing.

Salacuse, J. (2007)“Is There a Better Way? Alternative Methods of Treaty-Based, Investor-State Dispute Resolution.” 31 Fordham International Law Journal.

Sornarajah, S. (2004) The International Law on Foreign Investment, Cambridge: Cambridge University Press.

UNCTAD (2005) "Investor-State Disputes Arising from Investment Treaties: A Review," UNCTAD Series on International Investment Policies for Development: United Nations.

Weiler, T.(2005), ed., International Investment Law and Arbitration -Leading Cases from the ICSID, NAFTA, Bilateral Treaties and Customary International Law, London: Cameron May. 